Sports Endocrinology 
Frontiers of Hormone Research

\section{Vol. 47}

Series Editor

Ezio Ghigo Turin

Co-Editor

Federica Guaraldi Turin 


\section{Sports Endocrinology}

Volume Editors

Fabio Lanfranco Turin

Christian J. Strasburger Berlin

13 figures, 5 in color, and 13 tables, 2016

KARGER R 
Frontiers of Hormone Research

Founded 1972 by Tj.B. van Wimersma Greidanus, Utrecht

Continued by Ashley B. Grossman, Oxford (1996-2013)

Fabio Lanfranco, MD

Division of Endocrinology, Diabetology and

Metabolism

Department for Medical Sciences

University of Turin

Turin (Italy)
Christian J. Strasburger, MD

Department of Medicine for Endocrinology, Diabetes and Nutritional Medicine

Charité Universitätsmedizin

Berlin (Germany)

Library of Congress Cataloging-in-Publication Data

Names: Lanfranco, Fabio, editor. | Strasburger, Christian J., editor.

Title: Sports endocrinology / volume editors, Fabio Lanfranco, Christian

Strasburger.

Other titles: Sports endocrinology (Lanfranco) | Frontiers of hormone

research ; v. 47. 0301-3073

Description: Basel ; New York : Karger, 2016. | Series: Frontiers of hormone

research, ISSN 0301-3073; vol. 47 | Includes bibliographical references

and indexes.

Identifiers: LCCN 2016018631| ISBN 9783318058680 (hard cover : alk. paper) |

ISBN 9783318058697 (e-ISBN)

Subjects: | MESH: Sports--physiology | Endocrine Glands--physiology |

Hormones--metabolism | Exercise--physiology | Physical Fitness--physiology

| Doping in Sports

Classification: LCC QP571 | NLM QT 260 | DDC 612.4--dc23 LC record available at

https://lccn.loc.gov/2016018631

Bibliographic Indices. This publication is listed in bibliographic services, including Current Contents ${ }^{\circledR}$ and PubMed/MEDLINE.

Disclaimer. The statements, opinions and data contained in this publication are solely those of the individual authors and contributors and not of the publisher and the editor(s). The appearance of advertisements in the book is not a warranty, endorsement, or approval of the products or services advertised or of their effectiveness, quality or safety. The publisher and the editor(s) disclaim responsibility for any injury to persons or property resulting from any ideas, methods, instructions or products referred to in the content or advertisements.

Drug Dosage. The authors and the publisher have exerted every effort to ensure that drug selection and dosage set forth in this text are in accord with current recommendations and practice at the time of publication. However, in view of ongoing research, changes in government regulations, and the constant flow of information relating to drug therapy and drug reactions, the reader is urged to check the package insert for each drug for any change in indications and dosage and for added warnings and precautions. This is particularly important when the recommended agent is a new and/or infrequently employed drug.

All rights reserved. No part of this publication may be translated into other languages, reproduced or utilized in any form or by any means electronic or mechanical, including photocopying, recording, microcopying, or by any information storage and retrieval system, without permission in writing from the publisher.

(c) Copyright 2016 by S. Karger AG, P.O. Box, CH-4009 Basel (Switzerland)

www.karger.com

Printed in Germany on acid-free and non-aging paper (ISO 9706) by Kraft Druck GmbH, Ettlingen

ISSN 0301-3073

e-ISSN 1662-3762

ISBN 978-3-318-05868-0

e-ISBN 978-3-318-05869-7 


\section{Contents}

\section{Foreword}

Ghigo, E.; Guaraldi, F. (Turin)

vilI Preface

Lanfranco, F. (Turin); Strasburger, C.J. (Berlin)

Effects of Physical Activity and Training on Endocrine Function

1 Growth Hormone-Insulin-Like Growth Factor Axis, Thyroid Axis, Prolactin, and Exercise

Hackney, A.C.; Davis, H.C.; Lane, A.R. (Chapel Hill, N.C.)

12 Exercise and the Hypothalamo-Pituitary-Adrenal Axis

Duclos, M. (Clermont-Ferrand); Tabarin, A. (Pessac)

27 Exercise, Training, and the Hypothalamic-Pituitary-Gonadal Axis in Men and Women

Cano Sokoloff, N.; Misra, M.; Ackerman, K.E. (Boston, Mass.)

44 Metabolic Effects of Exercise

Moghetti, P.; Bacchi, E.; Brangani, C.; Donà, S.; Negri, C. (Verona)

58 Endocrine Responses to Exercise in the Developing Child and Adolescent

Richmond, E. (San José); Rogol, A.D. (Charlottesville, Va.)

68 Impact of Physical Exercise on Endocrine Aging

Janssen, J.A.M.J.L. (Rotterdam)

Use of Performance-Enhancing Endocrine Drugs (Doping) in Competitive and Recreational Sports Activity

82 Androgens

Iyer, R.; Handelsman, D.J. (Sydney, N.S.W.)

101 Growth Hormone and Insulin-Like Growth Factor-1

Nicholls, A.R.; Holt, R.I.G. (Southampton)

115 Erythropoietin

Jelkmann, W. (Lübeck)

128 Ergogenic Aids and Supplements

Porrini, M.; Del Bo', C. (Milan) 
153 Methods for Doping Detection

Ponzetto, F.; Giraud, S.; Leuenberger, N. (Lausanne); Boccard, J. (Geneva); Nicoli, R.;

Baume, N. (Lausanne); Rudaz, S. (Geneva); Saugy, M. (Lausanne)

168 Author Index

169 Subject Index 


\section{Foreword}

In the last decades, the effects of physical activity on endocrine and metabolic functions have gained growing interest in the scientific world, not only among endocrinologists. On the other hand, the increasing availability of ergogenic aids and supplements for professional athletes and amateurs on the market has galvanized the debate on the potential short- and long-term positive and negative consequences of these substances.

Indeed, the pivotal role exerted by hormones and other peptides with paracrine and endocrine action on body homeostasis (in both basal and stressful conditions) and physical performance (through the modulation of both resistance and endurance) is well known. On the other hand, both acute and chronic exercise have important effects on the functioning of several organs and systems, mainly mediated by the endocrine and neuroendocrine system.

Not only a multitude of environmental factors, including dietary practices for both macronutrients and supplements, but also training characteristics (i.e. intensity, time of day, and duration), age, gender, and circadian hormone secretion patterns have a strong impact on the interactions between exercise and endocrine function.

This volume of the series Frontiers of Hormone Research provides an authoritative overview on the most innovative, and sometimes still debated, topics in sports endocrinology. The first section of this volume explores the effects of physical activity on endocrine and metabolic functions in relation to exercise performance, growth, development, and aging. The second section presents the main characteristics and effects of performance-enhancing endocrine drugs, as well as techniques for their detection.

We are proud to present Fabio Lanfranco and Christian J. Strasburger's book entitled Sports Endocrinology, both of them experts in the field. We truly believe that this book will be attractive and useful for endocrinologists as well as physicians, physiologists, pharmacologists, and internists involved in the field of sports medicine, and we are grateful to all contributors that have made this volume what it is.

Ezio Ghigo, Turin

Federica Guaraldi, Turin 


\section{Preface}

Physical activity exerts an important influence on the endocrine system, modulating synthesis and secretion of several hormones. Almost every organ and system in the body is affected by physical activity and exercise, mainly through the endocrine and neuroendocrine system. Mode, intensity, and duration of the exercise bout, gender, age, and fitness level of the individual, as well as environmental and psychological factors may affect the endocrine response to physical activity.

In this book, the effects of physical activity and training on the endocrine function are extensively discussed and related to exercise performance, growth, development, and aging. A substantial part of this volume is devoted to the 'hot topic' of hormonal doping in sports. During the past decades, hormone abuse has become a widespread habit among professional and recreational athletes. The properties of androgens, growth hormone, erythropoietin as well as dietary supplements and their use and misuse in sports are described. Specific methods to detect hormone abuse are presented and discussed.

The contributors to this volume are well-known experts in the fields of sports medicine and endocrinology, endocrine physiology, pharmacology, and doping detection.

The purpose of this volume is to provide all professionals involved in sports medicine and endocrinology a state-of-the-art overview of the complex interactions between physical activity and the endocrine system and to focus on hormone use and abuse in sports at competitive and recreational level, highlighting its negative longterm consequences for health.

Fabio Lanfranco, Turin

Christian J. Strasburger, Berlin 